\title{
Diet and trophic guilds of fish assemblages in two streams with different anthropic impacts in the northwest of Paraná, Brazil
}

\author{
Karine Orlandi Bonato ${ }^{1}$, Rosilene Luciana Delariva² \& Jislaine Cristina da Silva ${ }^{3}$ \\ 1 Programa de Pós-Graduação em Ciências Biológicas Zoologia, Departamento de Zoologia, Universidade Federal do Paraná. \\ Caixa Postal 19020, 81531-980 Curitiba, PR, Brazil. \\ ${ }_{2}^{2}$ Corresponding author. Centro de Ciências Biológicas e da Saúde, Universidade Estadual do Oeste do Paraná. \\ Rua Universitária 2069, Caixa postal 711,85819-110 Cascavel, PR, Brazil. E-mail: rldelariva@hotmail.com \\ ${ }_{3}^{3}$ Programa de Pós-Graduação em Conservação e Manejo de Recursos Naturais, Centro de Ciências Biológicas e da Saúde, \\ Universidade Estadual do Oeste do Paraná. Rua Universitária 2069, Caixa postal 711, 85819-110 Cascavel, PR, Brazil.
}

\begin{abstract}
In the present study, we describe the diets of the fish assemblages in two streams in the Maringá region of Paraná that are under the influence of different anthropic impacts. We also evaluate how the origin and use of food resources varies temporally and spatially and how the trophic organization of the fish assemblages differs between the two streams. Fish were collected every two months from October 2006 to October 2007 using sieves, seining and closing nets along two $50 \mathrm{~m}$ stretches of each stream. We used the volumetric method to analyze the stomach contents of 599 fish belonging to 15 species. We then employed ANOSIM, SIMPER, NMDS and cluster analyses (using the BrayCurtis index) to examine how different factors (species, stream, sampling site and season) influenced the diets of the assemblages. The dietary analysis revealed a total of 21 types of items consumed, with the most common being detritus and immature Diptera. Spatial factors resulted in differences in diets between the two streams, with detritus representing the material consumed most often in the Morangueiro stream and immature Diptera being the most consumed item in the Queçaba stream. SIMPER analysis indicated a 76.33\% dissimilarity between species' diets during the dry and rainy seasons, with detritus, immature Diptera and testate amoebae making the greatest contributions to this differentiation. In the Morangueiro stream, three trophic guilds were found: detritivorous, detritivorous/aquatic insectivorous, and aquatic insectivorous. In Queçaba stream, six trophic guilds were present: detritivorous, benthophagous, aquatic insectivorous, terrestrial insectivorous, herbivorous and carnivorous. Autochthonous items were generally the items most consumed by species, in particularly in the Queçaba stream. In the Morangueiro stream, food items of indeterminate origin were more relevant. The differences in the diets of fish species between the two streams support the conclusion that urbanization causes the disruption of aquatic environments and trophic organization.
\end{abstract}

KEY WORDS. Food resources; seasonality; spatial variation; urbanization.

Research on tropical streams has intensified in recent years, particularly in southern and southeastern Brazil, highlighting several ecological aspects of these important ecosystems (CAsatti et al. 2006a, LANGEAni et al. 2007, VAlÉrio et al. 2007, Gomiero \& Braga 2008, Felipe \& Suarez 2010). Tropical streams constitute extensive water networks, though individual streams are small in size, and these waterways, exhibit a peculiar fauna that is very sensitive to the increasing degradation of the habitat (Oliveira \& Bennemann 2005, Cunico et al. 2011). Vitouser et al. $(1997,2008)$ reported that more than half of existing freshwater is used by human populations, and approximately half of all terrestrial landscapes have been altered by human activities, resulting in a great loss of biodiversity.

In recent years, the rapid radial expansion of urban centers over tropical streams, coupled with the heavy consumption of their resources and the subsequent disposal of materials in them, has contributed to their degradation. In particular, this has led to a reduction in the complexity of different habitats that make up aquatic ecosystems and landscapes (HeLms \& Feminella 2005, McKinney 2006, Casatti et al. 2009, Di Giulio et al. 2009). Studies performed by Cunico et al. (2006, 2011) showed that urbanization leads to changes in the diversity and species composition of tropical stream fish assemblages due to the loss of forested areas, reductions in water quality because of domestic and industrial sewage, and alterations of water flow and available substrates.

Changes in water quality or habitat conditions usually result in differences in the availability of food resources. Fish generally display high trophic plasticity (AвelHa et al. 2001) and temporal and spatial variations in their diets (Zeug \& Winemiller 2008, Derar et al. 2009). However, in impacted environments, these patterns can be altered, and changes, such 
as increases in generalist species and reduced numbers of trophic guilds, can occur (CASATti et al. 2009, AleXandre et al. 2010, Esteves $\&$ Alexandre 2011).

Evaluation of the feeding habits of fish in streams under the influence of different human impacts represents a key tool for assessing the biotic integrity of these streams and managing such environments. It also provides a consistent approach for understanding interactive processes within aquatic communities. Variations in the trophic organization of assemblages can be considered to be indicators of changes in the quality and complexity of a habitat (Karr 1981, Jaramillo \& Caramaschi 2008).

In this context, a number of studies have been undertaken to examine the urban streams in the state of Paraná. However, these studies have mainly focused on the influence of urbanization on the species composition and richness of fish assemblages (Cunico et al. 2006, Vieira \& Shibatta 2007, Cunico et al. 2009, Gubiani et al. 2010, Cunico et al. 2011). Only Oliveira \& Bennemann (2005) have evaluated the diet of sampled species in the Londrina Municipality region. Therefore, we aimed to describe the diet of the fish assemblages in two streams under the influence of different anthropic impacts in the region of Maringá, Paraná to evaluate how the origin and use of food resources varied temporally and spatially in these assemblages and whether the trophic organization of assemblages differed between the two streams.

\section{MATERIAL AND METHODS}

We studied two third order streams, Morangueiro and Queçaba, which are indirect and direct tributaries, respectively, of the Pirapó River. This river is a source of public water supplies for Maringá and is located in the northern region of the state of Paraná. It rises in the municipality of Apucarana and runs for a length of $168 \mathrm{~km}$ until reaching its mouth at the Paranapanema River. Morangueiro stream rises and runs for approximately $40 \%$ of its course through the urban perimeter of Maringá, with the remainder of the stream running through agricultural areas. Queçaba stream runs through agricultural areas, small recreation centers, and fish farms. Four sampling sites were established: two in each stream, with one at the headwater and another near the mouth (Fig. 1). Qualitative characteristics of the sampling sites are described in Table I.

Fish were sampled every two months from October 2006 to October 2007 at each of the four sampling sites using sieves (65 $\mathrm{cm}$ in diameter, $3 \mathrm{~mm}$ mesh size) and seining and closing nets ( $0.5 \mathrm{~cm}$ between opposite nodes). The sieves were used at the margins and on the substrate of the river beds, with sampling being performed for an initial period of 15 minutes and, after an interval of 20 minutes, for another five minutes to catch additional specimens, representing a total collection effort of 20 minutes. A seining net installed at the downstream end of the sampled stretch was hauled upstream of the $50 \mathrm{~m}$ length of the stream delimited at each site. After being captured, fish were anesthetized with benzocaine $(250 \mathrm{mg} / \mathrm{L})$ and fixed in a $10 \%$ formalin solution.

In the laboratory, specimens were separated and identified according to Graça \& PAvanelli (2007) and preserved in $70 \%$ alcohol. Each collected specimen was weighed on an analytical scale, measured for standard and total lengths in $\mathrm{cm}$, and then eviscerated. For the analysis of stomach contents, we used only species for with $\mathrm{n}>5$.

Using optical and stereoscopic microscopes, food items were identified to the lowest possible taxonomic level using the identification keys provided by BICUDo \& BICUDo (1970) for algae and Mugnai et al. (2010) for invertebrates. The items were quantified using graduated test tubes and a glass counting plate (Hellawell \& Abel 1971) according to the volumetric method,

Table I. Physical characteristics of the sampling sites sampled in the the Morangueiro (sites 1 and 2) and Queçaba (sites 3 and 4 ) streams, Pirapó River Basin, Maringá, Paraná State.

\begin{tabular}{|c|c|c|c|c|c|c|}
\hline Sites & Coordinates & $\begin{array}{l}\text { Width } \\
\text { (m) }\end{array}$ & $\begin{array}{l}\text { Depth } \\
\text { (m) }\end{array}$ & Predominant substrate & Riparian vegetation & Observations \\
\hline 1 & $\begin{array}{l}23^{\circ} 23^{\prime} 16,5^{\prime \prime} \mathrm{S} \\
51^{\circ} 53^{\prime} 40,5^{\prime \prime} \mathrm{W}\end{array}$ & $4-6$ & $0.2-1.0$ & Rocky & $\begin{array}{l}\text { Approximately } 5 \mathrm{~m} \text { of arboreal } \\
\text { vegetation; shrubby, with exotic } \\
\text { and fruit trees }\end{array}$ & $\begin{array}{l}\text { Erosion at the margins } \\
\text { Located in an urban area } \\
\text { Solid waste at the margins and in } \\
\text { the river } \\
\text { Some pools reach a } 1 \mathrm{~m} \text { depth }\end{array}$ \\
\hline 2 & $\begin{array}{l}23^{\circ} 20^{\prime} 20,41^{\prime \prime} \mathrm{S} \\
051^{\circ} 51^{\prime} 5,25^{\prime \prime} \mathrm{W}\end{array}$ & $6-8$ & $0.2-0.8$ & $\begin{array}{l}\text { Sandy stretches with } \\
\text { pebbles }\end{array}$ & $\begin{array}{l}\text { Arboreal vegetation at left margin } \\
\text { and grasses and shrubs at right } \\
\text { margin }\end{array}$ & $\begin{array}{l}\text { Preserved area on the right } \\
\text { margin, surrounding of the left } \\
\text { margin with cultivars }\end{array}$ \\
\hline 3 & $\begin{array}{l}23^{\circ} 19^{\prime} 24,41^{\prime \prime} \mathrm{S} \\
51^{\circ} 53^{\prime} 25,19^{\prime \prime} \mathrm{W}\end{array}$ & $2-3$ & $0.1-0.3$ & $\begin{array}{l}\text { Few stretches with } \\
\text { pebbles, mostly muddy }\end{array}$ & $\begin{array}{l}\text { Arboreal vegetation for } \\
\text { approximately } 30 \mathrm{~m}\end{array}$ & $\begin{array}{l}\text { Surrounded with pasture and } \\
\text { cultivars } \\
\text { Pools up to } 0.5 \mathrm{~m}\end{array}$ \\
\hline 4 & $\begin{array}{l}23^{\circ} 18^{\prime} 40,6^{\prime \prime} \mathrm{S} \\
51^{\circ} 53^{\prime} 30,8^{\prime \prime} \mathrm{W}\end{array}$ & $3-4$ & $0.2-0.6$ & $\begin{array}{l}\text { Rocky, pebbles, sandy } \\
\text { and muddy }\end{array}$ & $\begin{array}{l}\text { Arboreal and shrubby vegetation } \\
\text { for approximately } 20 \mathrm{~m}\end{array}$ & $\begin{array}{l}\text { Surrounding with pasture and } \\
\text { cultivars } \\
\text { Pools up to } 0.6 \mathrm{~m}\end{array}$ \\
\hline
\end{tabular}


BRAZIL
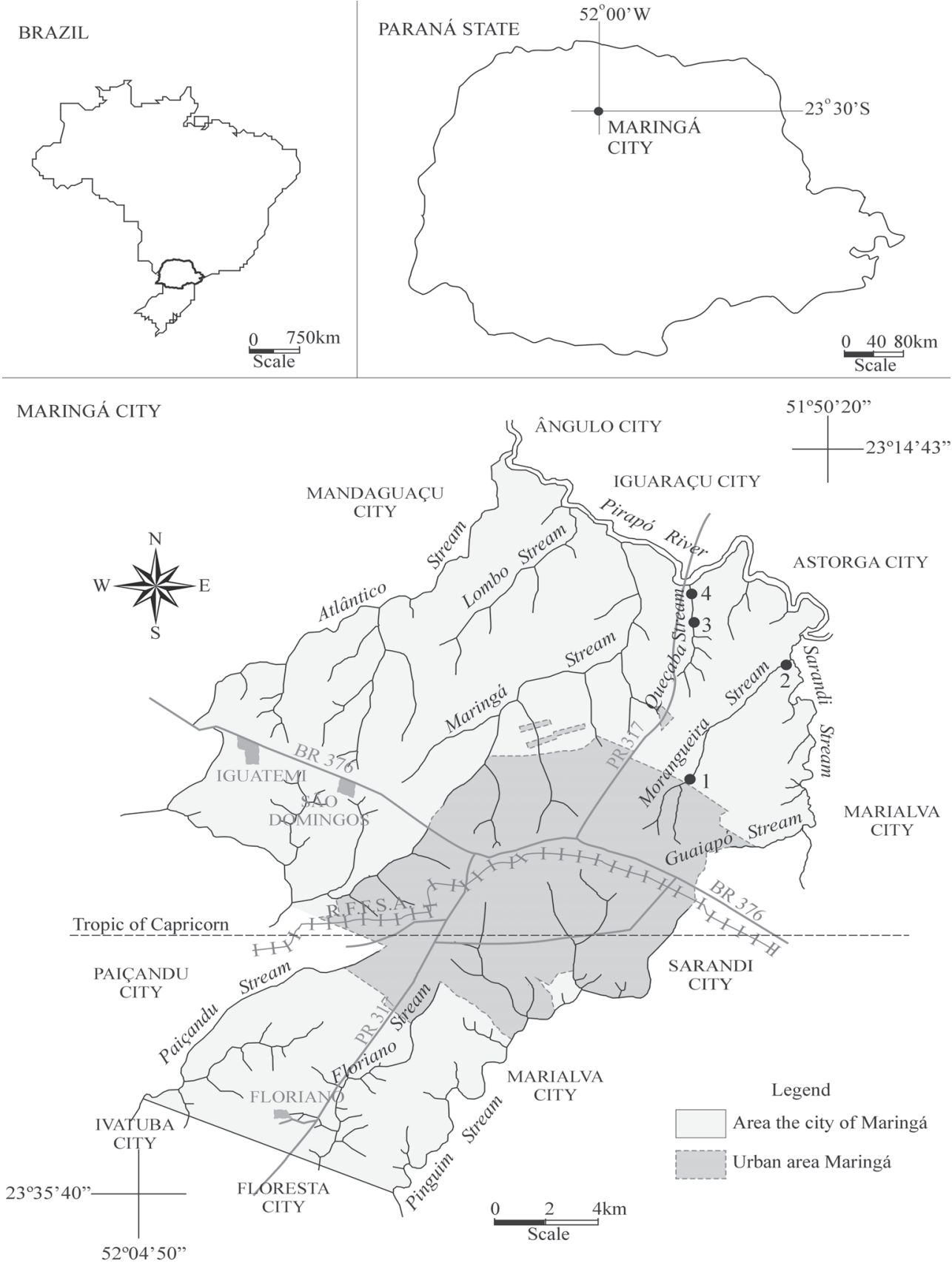

Figure 1. Sampling sites for the Queçaba and Morangueiro streams in the state of Paraná, Brazil.

where the total volume of a food item consumed by a population is given as a percentage of the total volume of all stomach contents (HysLop 1980).

Items with a low volumetric representation were categorized as other aquatic invertebrates (Acarina, Cladocera, Copepoda, Rotifera, Gastropoda, and Oligochaeta), algae (dia- toms and filamentous) or detritus (including all types of organic and inorganic material from the bottom).

To examine the influence of urbanization on fish diets, we focused on four factors: species, stream (Morangueiro and Queçaba), site (sites 1, 2, 3 and 4), and season (either rainy Oct-Dec 2006, Feb-Oct 2007) or dry (Apr/Jun/Aug 2007), es- 
tablished based on rainfall data obtained from the Climatological Station of the Universidade Estadual de Maringá. To analyze how the diet of the fish was related to these factors, we used the statistical package PRIMER-E v. 6.0 (Clarke \& Gorley 2001). Similarity matrices between samples were constructed using the Bray-Curtis index (Legendre \& Legendre 1998), and data were standardized (as a percentage) to minimize the discrepancy between samples.

After obtaining these matrices, we performed a one-way analysis of similarity (ANOSIM) to evaluate which of the factors significantly influenced which food items were consumed (global $\mathrm{R}>0$ and $\mathrm{p} \leqslant 0.05$ ). A posteriori, we performed a cluster ordination (dendrogram) using the UPGMA method with complete linkage to detect whether the samples were grouped according to the different factors (Legendre \& Legendre 1998, Clarke \& GoRley 2001). We then performed non-metric multidimensional scaling (NMDS) to examine the dispersion of the samples on a multidimensional scale (represented by a twodimensional graph) indicating the badness-of-fit, or "stress", of its representation. Finally, we used discriminant (similarity percentage) analysis to demonstrate the dissimilarities between the groupings and the contribution of different food items (Legendre \& Legendre 1998, Clarke \& Gorley 2001).

To determine trophic guilds for the species analyzed from each stream, we used the data collected regarding food item volumes to generate a similarity matrix using PRIMER-E v. 6.0 software. We then performed a cluster analysis using the BrayCurtis index. For classification into guilds, we only used groupings of species with a similarity greater than $55 \%$.

To examine the origin of the food items, they were classified as autochthonous, allochthonous or indeterminate. We only used the factors species, stream, site and season, and we followed the same methodology as described earlier using PRIMER software, but with overlapping clusters (circles) delimiting groups.

\section{RESULTS}

\section{Diet analysis and spatial and temporal variation}

We collected 1,393 individuals belonging to 23 species. Among these fish, the diets of 15 species were described based on analysis of the stomach contents of 599 individuals (Tab. II). The species consumed 21 types of food items. Of these items, 12 were categorized as autochthonous, eight as allochthonous, and one was considered indeterminate (Tab. III). The most consumed types of items were immature Diptera ( $28 \%$ of the total resources consumed), which were consumed by all species, and detritus ( $20 \%$ of the total resources consumed), which was consumed by $93 \%$ of the species. The other items, consumed in lower proportions, were Ephemeroptera (8\%), vegetal fragments (7\%) and fragments of terrestrial insects (6\%).

ANOSIM demonstrated the influence of the factor "species" (Global $\mathrm{R}=0.377, \mathrm{p}=0.001$ ). In the NMDS analysis, we observed the formation of groupings based on the differenti- ated use of food resources between species with a "stress" of 0.14 (Fig. 2). This was also supported by SIMPER analysis. Based on these results, we were able to determine which items contributed most to the formation of the following groups (i.e., to the similarity within species): Astyanax bockmanni Vari \& Castro, 2007 (Characidae), Bryconamericus stramineus Eigenmann, 1908 (Characidae), Characidium aff. zebra Eigenmann, 1909 (Crenuchidae), Imparfinis mirini Haseman, 1911 (Heptapteridae), Pimelodella gracilis (Valenciennes, 1835) (Heptapteridae), Rhamdia quelen (Quoy \& Gaimard, 1824) (Heptapteridae) and Rineloricaria sp. (Loricariidae) consumed immature Diptera (> 60\%); Gymnotus inaequelabiatus (Valenciennes, 1839) (Gymnotidae) consumed Ephemeroptera (56.1\%) and immature Diptera (39.8\%); Astyanax altiparanae Garutti \& Britski, 2000 (Characidae) consumed Coleoptera (45.6\%) and Hymenoptera (40.8\%); Piabina argentea Reinhardt, 1867 (Characidae) consumed immature Diptera (37.9\%) and vegetal fragments (31.1\%); Astyanax aff. paranae Eigenmann, 1914 (Characidae) consumed vegetal fragments (55.8\%) and immature Diptera (30.1\%); Corydoras aeneus (Gill, 1858) consumed testate amoebae (50.3\%) and detritus (27.8\%); and Hypostomus ancistroides (Ihering, 1905) (Loricariidae), Hypostomus cf. strigaticeps (Regan, 1908) (Loricariidae), and Poecilia reticulata Peters, 1859 (Poecilidae) consumed detritus (>75\%).

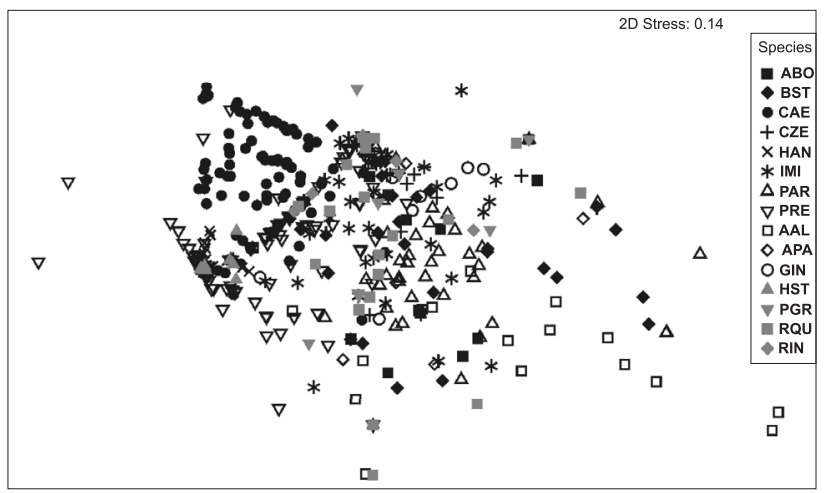

Figure 2. Two-dimensional plot of the fifteen species analyzed showing the ordination resulting from the NMDS. $A B O=$ Astyanax bockmanni; $\mathrm{AAL}=$ Astyana altiparanae; $\mathrm{APA}=$ Astyanax aff. paranae; $\mathrm{BST}=$ Bryconamericus stramineus; $\mathrm{CAE}=$ Corydoras aeneus; $\mathrm{CZE}=$ Characidium aff. zebra; GIN = Gymnotus inaequilabiatus; HAN = Hypostomus ancistroides; HST = Hypostomus cf. strigaticeps; $\mathrm{IMI}=$ Imparfinis mirini; $\mathrm{PAR}=$ Piabina argentea; $\mathrm{PGR}=$ Pimelodella gracilis; $\mathrm{PRE}=$ Poecilia reticulata; $\mathrm{RIN}=$ Rineloricaria sp.; $\mathrm{RQU}=$ Rhamdia quelen .

The factors "stream" (Global $\mathrm{R}=0.09, \mathrm{p}=0.001$ ) and "site" (Global R = 0.106, p = 0.001) were significant in the differentiation of diet between species. For the Morangueiro and Queçaba streams, the most consumed items were detritus (68.0\%) and immature Diptera (39.6\%), respectively. At site 4, 
Table II. Taxonomic position and number of stomachs analyzed for the fish species from the sampled streams. The list of species recorded and their taxonomic positions are consistent with Reis et al. (2003) and Graça \& Pavanelu (2007).

\begin{tabular}{|c|c|c|c|}
\hline Species & Species code & Voucher specimens & $\mathrm{N}$ analyzed stomachs \\
\hline \multicolumn{4}{|l|}{ Characiformes } \\
\hline \multicolumn{4}{|l|}{ Characidae } \\
\hline Astyanax altiparanae Garutti \& Britski, 2000 & AAL & 5290,5308 & 19 \\
\hline Astyanax bockmanni Vari \& Castro, 2007 & $\mathrm{ABO}$ & 5262 & 19 \\
\hline Astyanax aff. paranae Eigenmann, 1914 & APA & 5317 & 10 \\
\hline Bryconamericus stramineus Eigenmann, 1908 & BST & 5298 & 29 \\
\hline Piabina argentea Reinhardt, 1867 & PAR & 5291,5309 & 43 \\
\hline \multicolumn{4}{|l|}{ Crenuchidae } \\
\hline Characidium aff. zebra Eigenmann, 1909 & CZE & 5294 & 25 \\
\hline \multicolumn{4}{|l|}{ Cyprinodontiformes } \\
\hline \multicolumn{4}{|l|}{ Poecilidae } \\
\hline Poecilia reticulata Peters, 1859 & PRE & 5292 & 161 \\
\hline \multicolumn{4}{|l|}{ Gymnotiformes } \\
\hline \multicolumn{4}{|l|}{ Gymnotidae } \\
\hline Gymnotus inaequilabiatus (Valenciennes, 1839) & GIN & 5310 & 11 \\
\hline \multicolumn{4}{|l|}{ Siluriformes } \\
\hline \multicolumn{4}{|l|}{ Callichthyidae } \\
\hline Corydoras aeneus (Gill, 1858) & $\mathrm{CAE}$ & 5293,5296 & 99 \\
\hline \multicolumn{4}{|l|}{ Heptapteridae } \\
\hline Imparfinis mirini Haseman, 1911 & IMI & 5297 & 58 \\
\hline Pimelodella gracilis (Valenciennes, 1835) & PGR & 5307 & 9 \\
\hline Rhamdia quelen (Quoy \& Gaimard, 1824) & RQU & 5282 & 24 \\
\hline \multicolumn{4}{|l|}{ Loricariidae } \\
\hline Hypostomus ancistroides (Ihering, 1905) & HAN & ND & 66 \\
\hline Hypostomus cf. strigaticeps (Regan, 1908) & HST & 5283 & 12 \\
\hline Rineloricaria sp. & RIN & 5299,5311 & 14 \\
\hline Total Number & & & 599 \\
\hline
\end{tabular}

there was a predominance of immature Diptera (43.4\%) and a more contribution from other resources, such as vegetal fragments (9.3\%), Ephemeroptera (8.1\%) and Hymenoptera (6.9\%). At the sites 1, 2 and 3 detritus was the most consumed item based on results obtained from the SIMPER analysis.

This analysis also showed that for the factor "season" (Global $\mathrm{R}=0.027, \mathrm{p}=0.001$ ), there was a dissimilarity of $76.3 \%$ between the dry and rainy seasons. In the dry season, the predominant food item category for all species was detritus (73\%), while in the rainy season, the most consumed items were immature Diptera (49\%).

\section{Trophic classification}

Based on the volume of consumed items in each stream, the species were grouped into trophic guilds, with the grouping analysis corroborating our conclusion that the species within the assemblages formed distinct groups (Figs 3 and 4).
For the Morangueiro stream, three trophic guilds were established: detritivorous/aquatic insectivorous, comprised of $P$. reticulata and $C$. aeneus, both of which consumed detritus along with aquatic insects; detritivorous, including only $H$. ancistroides, which predominantly consumed detritus; and aquatic insectivorous, consisting of the majority (10 out of 15 ) of species studied (B. stramineus, A. bockmanni, P. gracilis, I. mirini, C. aff. zebra, Rineloricaria sp., $R$. quelen, $P$. argentea, $A$. aff. paranae and $A$. altiparanae), all of which consumed a higher proportion of aquatic insects.

In the Queçaba stream, six trophic guilds were formed: aquatic insectivorous, comprised of seven of the 15 species studied (P. gracilis, B. stramineus, P. argentea, G. inaequelabiatus, C. aff. zebra, I. mirini and A. bockmanni), which mainly consumed aquatic insects; carnivorous, including only $R$. quelen, which consumed both fish and aquatic insects; herbivorous, consisting of $A$. aff. paranae, for which the diet was based on vegetal 

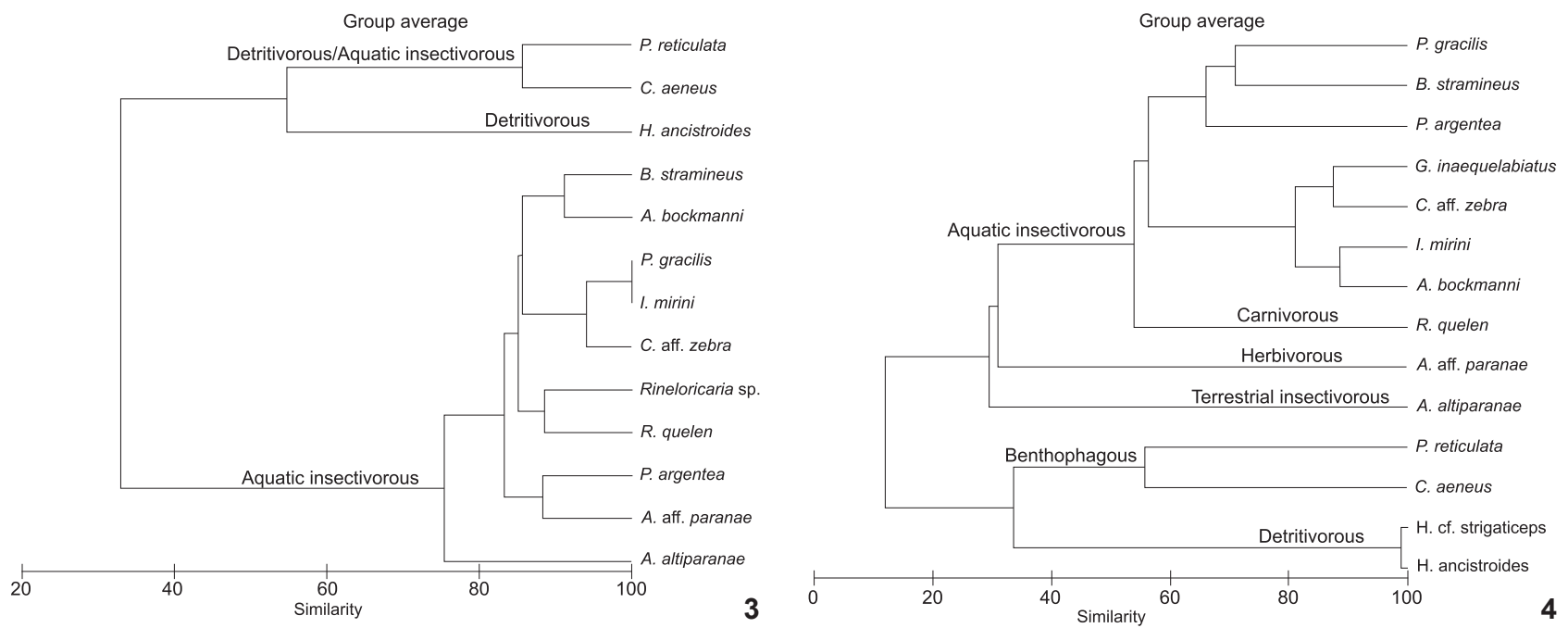

Figures 3-4. Similarity dendrogram based on the diet composition of the fifteen species of fish analyzed in (3) Morangueiro and (4) Queçaba streams, PR, Brazil.

Table III. Food items consumed by the studied species and the origin of the food items. Values are based on data indicating the volume percentage of the item consumed. Asterisk indicates values less than $0.1 \%$. The most significant values for each species are shown in bold.

\begin{tabular}{|c|c|c|c|c|c|c|c|c|c|c|c|c|c|c|c|}
\hline Food items & AAL & $\mathrm{ABO}$ & APA & BST & CZE & CAE & GIN & HAN & HST & IMI & PAR & PGR & PRE & RQU & RIN \\
\hline \multicolumn{16}{|l|}{ Autochthonous } \\
\hline Algae & & & & & & 0.1 & & 11.4 & * & * & & & 2.1 & * & 0.3 \\
\hline Testate amoebae & & & & & * & 51.6 & * & 0.4 & 1.5 & 0.3 & 0.2 & 0.1 & 2.9 & * & \\
\hline Conchostraca & & * & & 0.6 & * & 6.0 & & * & * & 0.8 & * & & & * & \\
\hline Immature Coleoptera & * & & & & 0.3 & & 3.0 & & & 0.2 & 2.0 & 0.3 & & 4.1 & \\
\hline Immature Diptera & 3.7 & 60.2 & 9.8 & 44.9 & 67.6 & 18.5 & 34.7 & 0.5 & 0.2 & 39.4 & 15.8 & 22.6 & 28.0 & 31.0 & 66.0 \\
\hline Ephemeroptera & 0.1 & 6.2 & & 2.1 & 15.6 & 0.8 & 36.3 & & & 18.6 & 5.1 & 1.4 & 1.6 & 3.8 & 1.3 \\
\hline Immature Lepidoptera & * & & & 3.7 & & & & & & 5.3 & 4.6 & & & 5.8 & 5.3 \\
\hline Odonata nymph & & 0.9 & & & & 0.3 & 3.1 & & & & 2.5 & 37.8 & & 8.2 & \\
\hline Trichoptera & & * & 7.7 & 0.6 & 13.9 & 0.6 & 9.6 & & & 10.7 & 3.4 & & & 2.4 & 12.9 \\
\hline Aquatic insects fragments & 4.8 & 0.4 & 13.3 & & & 1.0 & & & & 1.0 & 10.8 & & 2.3 & 0.6 & \\
\hline Other aquatic invertebrates & & 12.1 & & 2.9 & 0.3 & 1.0 & & * & & 2.8 & 0.7 & 5.5 & 0.9 & 2.8 & \\
\hline Fish & * & * & 0.6 & & & & 0.1 & & & & & & & 24.9 & \\
\hline \multicolumn{16}{|l|}{ Allochthonous } \\
\hline Vegetal fragments & 4.5 & 7.3 & 58.1 & 0.8 & 1.9 & 0.1 & 0.4 & & 0.7 & 2.4 & 27.7 & 0.8 & 1.2 & 1.3 & \\
\hline Arachinida & & 7.2 & & 3.2 & & & & & & & & & & 3.2 & \\
\hline Coleoptera & 34.8 & 0.5 & & 2.9 & & & & & & 0.1 & 9.1 & & & & \\
\hline Adult Diptera & & & & 3.5 & & & & & & & 0.5 & & & & \\
\hline Hemiptera & & & 6.1 & 6.1 & & & & & & 5.7 & 2.9 & & & & \\
\hline Hymenoptera & 37.3 & 5.1 & 0.3 & 14.5 & & & & & & & 11.0 & 2.1 & & * & \\
\hline Orthoptera & 6.8 & & & 3.5 & & & & & & & 0.3 & & & & \\
\hline Terrestrial insects fragments & 2.8 & & 3.2 & 7.8 & & & 9.5 & & & 7.8 & 2.2 & 29.5 & 7.2 & 9.5 & \\
\hline \multicolumn{16}{|l|}{ Indeterminate } \\
\hline Detritus & 5.3 & & 1.0 & 3.1 & 0.5 & 20.1 & 3.3 & 87.7 & 97.6 & 5.0 & 1.4 & * & 53.8 & 2.4 & 14.2 \\
\hline
\end{tabular}

ZOOLOGIA 29 (1): 27-38, February, 2012 
fragments; terrestrial insectivorous, comprised of $A$. altiparanae, which predominantly consumed terrestrial insects; benthophagous, consisting of $P$. reticulata and $C$. aeneus, both of which consumed a large proportion of bottom items, such as testate amoebae and detritus; and detritivorous, comprised of two species of Hypostomus that mainly consumed detritus.

\section{Origin of resources}

All the factors related to the origin of the food items were significant based on ANOSIM, providing evidence of interspecific and spatial variations in the use of allochthonous, autochthonous and indeterminate resources. The SIMPER analysis for the factor "species" (Global $\mathrm{R}=0.276, \mathrm{p}=0.001$ ) revealed that eight of the 15 species studied consumed approximately $60 \%$ autochthonous resources; one consumed more than $60 \%$ allochthonous resources; and three consumed more than $60 \%$ resources of indeterminate origin. Only $H$. ancistroides and $H$. cf. strigaticeps did not consume allochthonous items. A. altiparanae and $A$. aff. paranae mostly consumed allochthonous resources, and B. stramineus consumed equal proportions of allochthonous and autochthonous items (Tab. IV).

In the SIMPER analysis, the factor "stream" (Global R = $0.105, \mathrm{p}=0.001$ ) indicated that autochthonous resources were used most by fish in the Queçaba stream. In the Morangueiro stream, however, indeterminate resources were more important. These results were confirmed by the NMDS representation with cluster overlap, in which the two streams formed different groupings according to the origin of the examined food resources with 50\% similarity and good two-dimensional representation ("stress" $=0.02$ ) (Fig. 5).

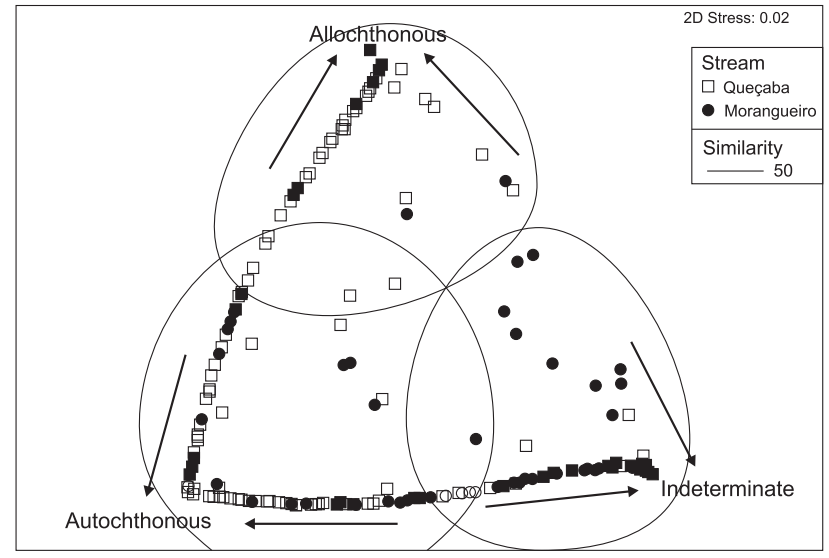

Figure 5. Two-dimensional plot of the NMDS analysis using the volume values grouped according to origin with symbols representing the factor "stream", which had an influence on cluster formation, as confirmed by ANOSIM (Global R $=0.105$ and $p=$ 0.001 ) and with overlapping clusters (circles) delimiting groups. The arrows indicate the direction of increase for the contribution of food items in the groupings.

With respect the factor "site" (Global R $=0.104, \mathrm{p}=0.001$ ), autoch thonous food items predominated, except at site 1 , where indeterminate resources were the most represented, and site 4, where there was a more significant contribution of allochthonous items (31.7\%). For the factor "season" (Global $\mathrm{R}=0.032$, $\mathrm{p}=0.001)$, autochthonous resources showed a $73 \%$ contribu-

Table IV. Values obtained via SIMPER analysis according to the origin (autochthonous, allochthonous and indeterminate) of the item consumed by the fifteen species.

\begin{tabular}{|c|c|c|c|c|}
\hline \multirow{2}{*}{ Species } & \multirow{2}{*}{ Similarity } & \multicolumn{3}{|c|}{ Percent Contribution of Origin } \\
\hline & & Autochthonous & Allochthonous & Indeterminate \\
\hline A. bockmanni & 48.82 & 64.58 & 35.42 & \\
\hline A. altiparanae & 54.05 & 10.05 & 89.52 & \\
\hline A. aff. paranae & 36.61 & 48.42 & 51.37 & \\
\hline B. aff. stramineus & 51.70 & 49.98 & 49.36 & \\
\hline C. aeneus & 65.34 & 82.37 & & 17.63 \\
\hline C. aff. zebra & 87.20 & 99.97 & & \\
\hline G. inaequelabiatus & 71.89 & 99.87 & & \\
\hline H. ancistroides & 95.81 & & & 99.78 \\
\hline H. cf. strigaticeps & 92.98 & & & 99.74 \\
\hline I. mirini & 56.77 & 91.69 & & \\
\hline P. argentea & 54.65 & 58.28 & 41.71 & \\
\hline P. gracilis & 51.11 & 76.93 & 23.07 & \\
\hline P. reticulata & 49.93 & 33.82 & & 64.89 \\
\hline R. quelen & 61.25 & 91.55 & & \\
\hline Rineloricaria sp. & 90.01 & 99.69 & & \\
\hline
\end{tabular}


tion during the rainy season and a $47 \%$ contribution during the dry season, while even in the dry season, resources of indeterminate origin presented a $50 \%$ contribution.

\section{DISCUSSION}

The dietary composition of the species we studied showed that they mainly consumed aquatic insects, which is a pattern that has been observed in neotropical streams by other authors (Casatti 2002, Motta \& Uieda 2004, Uieda \& Motta 2007, Winemiller et al. 2008, Vidotto-Magnoni \& Carvalho 2009). Detritus was also a large part of the diet of the fish assemblages, which has been reported for a number of species in natural environments (BOWEN 1983), especially in impacted streams (Oliveira \& Bennemann 2005, Ferreira \& Casatti 2006, Rocha et al. 2009).

The specific diet of each species was related to their different morphologies and trophic apparatuses, distinct feeding habits, and the use of different habitats and feeding tactics (Bowen, 1983, Piedras \& Pouey 2005, Brandão-Gonçalves et al. 2009, Oliverra et al. 2010). Moreover, these factors mitigated the effects of overlapping resource used and competition that might occur in locations where the food supply is limited to a few sources. Therefore, the use of a limited range of food resources by the investigated species is probably not related to food overlap or competition, but to the abundance of detritus and immature Diptera due to the availability of organic matter in these impacted environments.

The influence of spatial factors on the fish species' diets was related to the different characteristics of the streams as well as their surroundings. A well-structured site with a variety of habitats for feeding and shelter can support many species (CASATTI et al. 2006b). Such sites are associated with riparian vegetation and water quality. Nevertheless, the removal of this type of vegetation or changes in land cover and other artificial anthropogenic changes in these environments may affect streams, which directly affects the fish fauna in with respect to vital processes, such as feeding and reproduction (WALSH et al. 2005, Dias \& Tejerina-Garro 2010). In this context, Carvalho \& Uieda (2010) observed significant differences in the input of litter to the aquatic system between forested and non-forested areas. Thus, any qualitative or quantitative changes modify the structure of biotic communities, including the trophic chain (Pusey \& ARthington 2003). In degraded environments, the use of large quantities of items such as detritus as a food source is well documented, though mainly by introduced species tolerant to environmental disturbances and generalists, such as $P$. reticulata (Cunico et al. 2006, Ferreira \& Casatti 2006, Felipe \& Súarez 2010). This species was present in the sampled streams, particularly in Morangueiro, which is more degraded as a function of receiving a large load of urban pollution.

Oliveira \& Bennemann (2005) evaluated five sites at the Cambé stream in Londrina, where they found that detritus was the most abundant food item used by fish, which was also a result of the present study. Additionally, they only observed large contributions from terrestrial insects and plants at one site, similar to this study, in which we only detected a significant contribution of these food items at site 4 . These authors also emphasized that the high dominance of detritus being consumed by the investigated species differs from what is found for non-impacted streams and that this is mostly related to environmental changes. The ingestion of larger amounts of detritus at sites 1, 2 (Morangueiro) and 3 (Queçaba) can therefore be explained by the environmental changes at these locations, which are characterized by a greater degree of anthropic impact in comparison to site 4 .

The seasonal differences found in this study are caused by the type of food consumed, with predominance of detritus being observed during the dry season and immature Diptera making the greatest contribution in the rainy season. This is because in the dry season (colder months), arthropods are not usually available in high abundances, resulting in organic matter, specifically detritus, becoming the dominant source of food (MéronA \& RANKIN-DE-Mérona 2004). The opposite is true in the rainy season, when there is greater ingestion of aquatic insects, mainly Diptera, which was also reported by PINTO \& Uieda (2007) at the Quinta stream in Itatinga, state of São Paulo. In addition to the increased emergence of aquatic stages during summer discussed above, the variation between seasons is probably related to the greater input of organic matter transported by rainwater, which contributes to increasing the available substrate used by these invertebrates, which, in turn, increase in abundance.

The variation found in the use of food resources between streams was also evident in our observations regarding the formation of different guilds. Impacted streams present fewer trophic guilds, with species being more opportunistic and generalist and more flexible in their foraging (Poff \& AlLAN 1995, Roy et al. 2006). This was mainly caused by a decrease in the abundance of invertebrates due to the instability of urban aquatic environments (Jones \& Clark 1987). Some studies addressing urban streams have detected the presence of trophic groups such as omnivores and detritivores (CASATTI et al. 2009, AleXANDRe et al. 2010). This may be the result of a degradation of the food base, which provides opportunities for exploitation by more opportunistic and resistant species (ArAújo 1998, Flores-Lopes et al. 2010). According to AbelHa et al. (2001), trophic specialization among tropical fish is rare, and the apparent specialization shown by some species may be more related to the availability of food resources in the aquatic system than to actual trophic specialization by a species. This phenomenon is evident in streams, where a wide range of resources is available for fish assemblages (CASATTI 2002, CASATTI et al. 2009). Resources such as immature Diptera (Chironomidae) are common in impacted environments because these species are tolerant and can easily adapt to extreme conditions, including the presence of large amounts of nutrients such as phosphorous that come 
from domestic and industrial sources of pollution (KLeINE \& Trivinho-Strixino 2005, Milesi et al. 2009, Mormul et al. 2009). Therefore, groups resistant to these conditions reach high densities (Mormul et al. 2009) and are then preyed upon by large numbers of fish. This hypothesis is supported by the greater proportion of species we observed feeding on immature Diptera (mainly Chironomidae), which were abundant at the study sites.

At Queçaba stream, we observed herbivorous and terrestrial insectivorous guilds, neither of which was observed in the Morangueiro stream. This demonstrates that even though there was availability of existing vegetation in the Morangueiro stream, the fish species inhabiting this stream consumed food resources that were more abundant in the ecosystem, such as detritus and immature Diptera. In the literature, species of Astyanax are considered to be omnivorous at impacted sites (CASATTI et al. 2009, AlEXANDRE et al. 2010), and it is also well documented that this genus demonstrates considerable trophic opportunism (CASSEMIRO et al. 2002, Abelha et al. 2006, Teixeira \& Bennemann 2007). However, the difference between the streams investigated in the present study was remarkable: in Queçaba, there was a greater variety of resources, enabling increased differentiation in the diets of the species, allowing them to form terrestrial insectivorous, herbivorous and carnivorous guilds. This indicates greater trophic structuring at this location (ARAújo 1998), which is also supported by physical characteristics of the environment, such as the absence of domestic sewage and storm sewers and the presence of riparian vegetation.

Some authors have found that most of the food resources consumed by stream fish are of allochthonous origin (CASTRO 1999, Esteves \& Aranha 1999, Lowe-McConnell 1999, Alvin \& Peret 2004). In the present study, both allochthonous and autochthonous resources were used by fish assemblages. However, autochthonous resources dominated the diet of most species. This was also observed in studies performed by BRAGA \& Gomiero (2009) and Rondineli et al. (2011). The low contribution of allochthonous items can be explained by the disruption of riparian vegetation in the studied areas. Terrestrial insects and vegetal fragments were only consumed during the rainy season and only at site 4 , which consisted of a large area with riparian vegetation. Normally, the input of allochthonous material from both plants and animals in aquatic environments is greater in the rainy season, mainly because of the displacement of these organisms to the aquatic environment by rain and wind and the leaching of adjacent areas (ANGERMEIER \& KARR 1983, Rezende \& Mazzoni 2005, Tófoli et al. 2010).

The use of indeterminate material (detritus) as a food source is well documented for Hypostomus species (Gomiero \& Braga 2005, Oliveira \& Bennemann 2005, Gomiero \& Braga 2008, Brandão-Gonçalves et al. 2010), as is the predominant use of allochthonous resources (terrestrial insects and plants) by $A$. altiparanae and $A$. aff. paranae (Gomiero \& Braga 2005, 2008, Bennemann et al. 2005, CASATti 2002). In this study, B. stramineus was found to consume similar proportions of allochthonous and autochthonous items, which is in accord with the findings of ReZENDE \& MAZZONI (2006), who detected no differences in the consumption of allochthonous and autochthonous items in the diet of Bryconamericus microcephalus (Miranda Ribeiro, 1908 ) at a shaded site in the Andorinha stream, state of Rio de Janeiro. Meanwhile, Gomiero \& Braga (2005) emphasized that making inferences regarding the importance of allochthonous or autochthonous items in relation to the diet of broad and diverse community of fish is impaired due to the large number of interactions and differences in the feeding habits of these species, which is a result of the consumption of a wide range of resources according to their availability in the environment. Our study corroborated this plasticity.

Overall, we observed that there were both seasonal (characteristic of tropical environments) and spatial differences in the diets of the investigated fish. However, we noted that these variations were not the same as are normally found in non-impacted environments. The species addressed in the presented study almost exclusively made use of resources of autochthonous origin (mainly detritus and immature Diptera), thereby demonstrating self-trophic opportunism by eating the most available food resource in the ecosystem, which is common in areas of anthropogenic impact. The degree of disruption caused by urbanization in the Morangueiro stream was clear, as only three trophic guilds were found. Even the Queçaba stream, where there was a larger number of guilds and a better structured environment at site 4 , was not immune to anthropogenic impacts, particularly when considering the number of species that composed, for example, the aquatic insectivorous guild. Thus, our findings support the hypothesis that anthropogenic changes associated with urbanization cause disruption of aquatic environments and of the trophic organization of fish species.

\section{ACKNOWLEDGEMENTS}

We thank CESUMAR for providing logistical support for sampling and analyzing materials. Funding was provided by CNPq (Conselho Nacional de Desenvolvimento Científico e Tecnológico) process 115761/2007-1 to Karine Orlandi Bonato. We also thank Igor, Emanuel, Alex, Milena, Flávia, Ana, Maria Isabel and Beatriz for helping in the field work and Marcos Valduga for helping in statistical analysis.

\section{LITERATURE CITED}

Abelha, M.C.F.; A.A. Agostinho \& E. Goulart. 2001. Plasticidade trófica em peixes de água doce. Acta Scientiarum 23 (2): 425-434.

Abelha, M.C.F.; E. Goulart; E.A.L. Kashiwaqui \& M.R. Silva. 2006. Astyanax paranae Eigenmann, 1914 (Characiformes: Characidae) in the Alagados Reservoir, Paraná, Brazil: diet composition and variation. Neotropical Ichthyology 4 (3): 349-356. 
Alexandre, C.V.; K.E. Esteves \& M.A.M.M. Mello. 2010. Analysis of fish communities along a rural-urban gradient in a neotropical stream (Piracicaba River Basin, São Paulo, Brazil). Hydrobiologia 641: 97-114.

Alvim, M.C.C. \& A.C. Peret. 2004. Food resources sustaining the fish fauna in a section of the upper São Francisco River in Três Marias, MG, Brazil. Brazilian Journal of Biology 64 (2): 195-202.

Angermeier, P.L. \& J.R. Karr. 1983. Fish communities along environmental gradients in a system of tropical streams. Environmental Biology of Fishes 9: 117-135.

Araújo, F.G. 1998. Adaptação do índice de integridade biótica usando a comunidade de peixes para o rio Paraíba do Sul. Revista Brasileira de Biologia 58 (4): 547-558.

Bennemann, S.T.; A.M. Gealh; M.L. Orsi \& L.M. Souza. 2005. Ocorrência e ecologia trófica de quatro espécies de Astyanax (Characidae) em diferentes rios da bacia do rio Tibagi, Paraná, Brasil. Iheringia, Série Zoologia, 95 (3): 247-254.

Bicudo, C.E.M. \& R.M.T. Bicudo. 1970. Algas de águas continentais brasileiras chave ilustrada para identificação de gêneros. São Paulo, Fundação Brasileira para o Desenvolvimento do Ensino de Ciências, 227p.

Bowen, S. 1983. Detritivory in neotropical fish communities. Environmental Biology of Fishes 9 (2): 137-144.

Braga, F.M.S. \& L.M. Gomiero. 2009. Alimentação de peixes na microbacia do Ribeirão Grande, Serra da Mantiqueira Oriental, SP. Biota Neotropica 9 (3): 207-212.

Brandão-Gonçalves, L.; S.E. Lima-Junior \& Y.R. Suarez. 2009. Feeding habits of Bryconamericus stramineus Eigenmann, 1908 (Characidae), in different streams of Guiraí River Sub-Basin, Mato Grosso do Sul, Brazil. Biota Neotropica 9 (1): 135-143.

Brandão-Gonçalves, L.; S.A. Oliveira \& S.E. Lima-Junior. 2010. Hábitos alimentares da ictiofauna do córrego Franco, Mato Grosso do Sul, Brasil. Biota Neotropica 10 (2): 21-30.

Carvalho, E.M. \& V.S. Uieda. 2010. Input of litter in deforested and forested areas of a tropical headstream. Brazilian Journal of Biology 70 (2): 283-288.

Casatti, L. 2002. Alimentação dos peixes em um riacho do Parque Estadual Morro do Diabo, bacia do alto rio Paraná, sudeste do Brasil. Biota Neotropica 2 (2): 12-14.

Casatti, L.; F. Langeani \& C.P. Ferreira. 2006a. Effects of the physical habitat degradation on the stream fish assemblage structure in a pasture region. Environmental Management 38 (6): 974-982.

Casatti, L.; F. Langeani; A.M. Silva, \& R.M.C. Castro. 2006 b. Stream fish, water and habitat quality in a pasture dominated basin, southeastern Brazil. Brazilian Journal of Biology 66 (2B): 681-696.

Casatti, L.; C.P. Ferreira \& F. Langeani. 2009. A fish-based biotic integrity index for assessment of lowland streams in southeastern Brazil. Hydrobiologia 623: 173-189.

Cassemiro, F.A.S.; N.S. Hahn \& R. Fugi. 2002. Avaliação da dieta de Astyanax altiparanae Garutti \& Britski, 2000 (Osteichthyes, Tetragonopterinae) antes e após a formação do reservatório de Salto Caxias, Estado do Paraná, Brasil. Acta Scientiarum 24 (2): 419-425.

CASTRO, R.M.C. 1999. Evolução da ictiofauna de riachos sulamericanos: padrões gerais e possíveis processos causais, $p$. 139-155. In: E.P. Caramaschi; R. Mazzoni \& P.R. Peres Neto (Eds). Ecologia de peixes de riachos: estado atual e perspectivas. Rio de Janeiro, PPGE-UFRJ, Série Oecologia Brasiliensis 6.

Clarke, K.R. \& R.N. Gorley. 2001. PRIMER v. 5: User manual/ tutorial. Plymouth, PRIMER-E, 91p.

Cunico, A.M.; A.A. Agostinho \& J.D. Latini. 2006. Influência da urbanização sobre as assembléias de peixes em três córregos de Maringá, Paraná. Revista Brasileira de Zoologia 23 (4): 1101-1110.

Cunico, A.M.; J.D. Allan \& A.A. Agostinho. 2011. Functional convergence of fish assemblages in urban streams of Brazil and the United States. Ecological Indicators 11: 1354-1359.

Cunico, A.M.; W.J. da Graça; A.A. Agostinho; W.M. Domingues \& J.D. Latini. 2009. Fish, Maringá Urban Streams, Pirapó river drainage, upper Paraná river basin, Paraná State, Brazil. Check List 5 (2): 273-280.

Dekar, M.P.; D.D. Magoulick \& G.R. Huxel. 2009. Shifts in the trophic base of intermittent stream food webs. Hydrobiologia 635: 263-277.

Di Giulio, M.; R. Holderegger \& S. Tobias. 2009. Effects of habitat and landscape fragmentation on humans and biodiversity in densely populated landscapes. Journal of Environmental Management 90 (10): 2959-2968.

Dias, A.M. \& F.L. Tejerina-Garro. 2010. Changes in the structure of fish assemblages in streams along na undisturbedimpacted gradient, upper Paraná River basin, Central Brazil. Neotropical Ichthyology 8 (3): 587-598.

Esteves, K.E. \& J.M.R. Aranha. 1999. Ecologia trófica de peixes de riachos, p. 157-182. In: E.P. Caramaschi ; R. Mazzoni; C.R.S.F. Bizerril \& P.R. Peres-Neto (Eds). Ecologia de peixes de riachos: estado atual e perspectivas. Rio de Janeiro, PPGE-UFRJ, Série Oecologia Brasiliensis 6.

Esteves, K.E. \& C.V. Alexandre. 2011. Development of an Index of Biotic Integrity Based on Fish Communities to Assess the Effects of Rural and Urban Land Use on a Stream in Southeastern Brazil. International Review of Hydrobiology 963: 296-317.

Felipe, T.R.A. \& Y.R. SúAReZ. 2010. Caracterização e influência dos fatores ambientais nas assembléias de peixes de riachos em duas microbacias urbanas, Alto Rio Paraná. Biota Neotropica 10 (2): 143-151.

Ferreira, C.P. \& L. Casatti. 2006. Integridade biótica de um córrego na bacia do Alto Rio Paraná avaliada por meio da comunidade de peixes. Biota Neotropica 6 (3): 1-25.

Flores-Lopes, F.; M. Cetra \& L.R. Malabarba. 2010. Utilização de índices ecológicos em assembléias de peixes como instrumento de avaliação da degradação ambiental em programas de monitoramento. Biota Neotropica 10 (4): 183-193. 
Gomiero, L.M. \& F.M.S. Braga. 2005. Uso do grau de preferência alimentar para a caracterização da alimentação de peixes na APA de São Pedro e Analândia. Acta Scientiarum Biological Sciencies 27 (3): 265-270.

Gomiero, L.M. \& F.M.S. Braga. 2008. Feeding habits of the ichthyofauna in a protected area in the state of São Paulo, southeastern Brazil. Biota Neotropica 8 (1): 41-47.

Graça, W. J. \& C.S. Pavanelli. 2007. Peixes da planície de inundação do alto rio Paraná e áreas adjacentes. Maringá, EDUEM, 241p.

Gubiani, E.A.; V.S. Daga; V.A. Frana \& W.J. da Graça. 2010. Fish, Toledo urban streams, São Francisco Verdadeiro River drainage, upper Paraná River basin, state of Paraná, Brazil. Check List 6 (1): 45-48.

Hellawell, J.M. \& R.A. Aвel. 1971. Rapid volumetric method for the analysis of the food of fishes. Journal of Fish Biology 3: 29-37.

Helms, B.S. \& J.W. Feminella. 2005. Detection of biotic responses to urbanization using fish assemblages from small streams of western Georgia, USA. Urban Ecosystems 8: 39-57.

Hyslop, E.J. 1980. Stomach contents analysis: a review of methods and their application. Journal of fish Biology 17: 411-429.

JaRAmillo-Villa, U. \& E.P. CARAmaschi. 2008. Índices de integridade biótica usando peixes de água doce: Uso nas regiões tropical e subtropical. Oecologia Brasiliensis 12 (3): 442-462.

Jones, R.C. \& C.C. Clark. 1987. Impact of watershed urbanization on stream insect communities. Water Resources Bulletin 23: 1047-1055.

KARR, J.R. 1981. Assessment of biotic integrity using fish communities. Fisheries 6: 21-27.

Kleine, P. \& S. Trivinho-Strixino. 2005. Chironomidae and other aquatic macroinvertebrates of a first order stream: community response after habitat fragmentation. Acta Limnologica Brasiliensia 17 (1): 81-90.

Langeani, F.; R.M.C. Castro; O.T. Oyakawa; O.A. Shibatta; C.S. Pavanelli \& L. Casatti. 2007. Diversidade da ictiofauna do Alto Rio Paraná: composição atual e perspectivas futuras. Biota Neotropica 7 (3): 1-17.

Legendre, P. \& L. Legendre. 1998. Numerical Ecology. Elsevier, Amsterdam, $2^{\text {nd }}$ ed., 853p.

LoWe-Mcconnel, R.H. 1999. Estudos ecológicos de comunidade de peixes tropicais. São Paulo, EDUSP, 535p.

McKinney, M.L. 2006. Urbanization as a major cause of biotic homogenization. Biological Conservation 127: 247-260.

Mérona, B. \& J. Rankin-De-Mérona. 2004. Food resource partitioning in a fish community of the central Amazon floodplain. Neotropical Ichthyology 2 (2): 75-84.

Milesi, S.V.; C. Biasi; R.M. Restello \& L.U. Hepp. 2009. Distribution of benthic macroinvertebrates in Subtropical streams (Rio Grande do Sul, Brazil). Acta Limnologica Brasiliensia 21 (4): 419-429.

Mormul, R.P.; S. Pressinatte Junior; L.A. Vieira; A. Monkolski \& E.B. PovH. 2009. Caracterização das condições ambientais de um rio neotropical a partir da densidades, composição e riqueza de taxa de invertebrados bênticos. Acta Scientiarum Biological Sciences 31 (4): 379-386.

Motta, R.S. \&. V.S. Uieda. 2004. Dieta de duas espécies de peixes do ribeirão do Atalho, Itatinga, SP. Revista Brasileira de Zoociências 6 (2): 191-205.

Mugnai, R.; J.L. Nessimian \& D.F. Baptista. 2010. Manual de identificação de macroinvertebrados aquáticos do Estado do Rio de Janeiro. Rio de Janeiro, Technical Boocks, 174p.

Oliveira, D.C. \& S.T. BenNEmAn. 2005. Ictiofauna, recursos alimentares e relações com as interferências antrópicas em um riacho urbano no sul do Brasil. Biota Neotropica 5 (1): 96-107.

Oliveira, E.F.; E. Goulart; L. Breda; C.V. Minte-Vera; L.R.S. Paiva $\&$ M.R. VISMARA. 2010. Ecomorphological patterns of the fish assemblage in a tropical floodplain: effects of trophic spatial and phylogenetic structures. Neotropical Ichthyology 8 (3): 569-586.

Piedras, S.R.N. \& J.L.O.F. Pouey. 2005. Feeding of the silverside (Odontesthes bonariensis, Atherinopsidae) in the Mirim and Mangueira lagoons, Rio Grande do Sul, Brazil. Iheringia, Série Zoologia, 95 (2): 117-120.

PINTO, T.L. \& V.S. UiEDA. 2007. Aquatic insects selected as food for fishes of a tropical stream: Are there spatial and seasonal differences in their selectivity? Acta Limnologica Brasiliensia 19 (1): 67-78.

Poff, N.L. \& J.D. Allan. 1995. Stream fish assemblages in relation to hydrological variability. Ecology 76 (2): 606-627.

Pusey, B.J. \& A.H. Arthington. 2003. Importance of the riparian zone to the conservation and management of freshwater fish: a review. Marine and Freshwater Research 54: 1-16.

Rezende, C.F. \& R. MAZzons. 2005. Seasonal variation in the input of allochthonous matter in an Atlantic Rain Forest stream, Ilha Grande-RJ. Acta Limnologica Brasiliensia 17 (2): 167-175.

Rezende, C.F. \& R. MAzzoni. 2006. Contribuição da matéria autóctone e alóctone para a dieta de Bryconamericus microcephalus (Miranda-Ribeiro) (Actinopterygii, Characidae), em dois trechos de um riacho de Mata Atlântica, Rio de Janeiro, Brasil. Revista Brasileira de Zoologia 23 (1): 58-63.

Rocha, F.C.; L. Casatti \& D.C. Pereira. 2009. Structure and feeding of a stream fish assemblage in Southeastern Brazil: evidence of low seasonal influences. Acta Limnologica Brasiliensia 21 (1): 123-134.

Rondineli, G.; M. Gomiero,; A.L. Caramassi \& F.M.S. Braga. 2011. Diet of fishes in Passa Cinco stream, Corumbataí River subbasin, São Paulo state, Brazil. Brazilian Journal of Biology 71 (1): 157-167.

Roy, A.H.; M.C. Freeman; B.J. Freeman; S.J. Wenger; J.L. Meyer \& W.E. ENSIGN. 2006. Importance of riparian forest in urban catchments contingent on sediment and hydrologic regimes. Environmental Management 37 (4): 523-539.

Teixeira, I. \& S.T. Bennemann. 2007. Ecomorfologia refletindo a dieta dos peixes em um reservatório no sul do Brasil. Biota Neotropica 7 (2): 67-76. 
Tófoli, R.M.; N.S. Hahn; G.H.Z. Alves \& G.C. Novakowski. 2010. Uso do alimento por duas espécies simpátricas de Moenkhausia (Characiformes, characidae) em um riacho da Região CentroOeste do Brasil. Iheringia, Série Zoologia, 100 (3): 201-206.

UIEDA, V.S. \& R.L. MotTA. 2007. Trophic organization and food web structure of southeastern Brazilian streams: a review. Acta Limnologica Brasiliensia 19 (1): 15-30.

Valério, S.B.; Y.R. Súarez; T.R.A. Felipe; K.K. Tondato \& L.Q.L. XIMENES. 2007. Organization patterns of headwater-stream fish communities in the Upper Paraguay-Paraná basins. Hydrobiologia 583 (1):241-250.

Vidotto-Magnoni, A.P. \& E.D. Carvalho. 2009. Aquatic insects as the main food resource of fish the community in a Neotropical reservoir. Neotropical Ichthyology 7 (4): 701-708.

Vieira, D.B. \& O.A. Shibatta. 2007. Peixes como indicadores de qualidade ambiental do ribeirão Esperança, município de Londrina, Paraná, Brasil. Biota Neotropica 7 (1): 7-5.

Vitousek, P.M.; H.A. Mooney; J. Lubchenco \& J.M. Melillo. 1997.
Human domination of Earth's ecosystems. Science 277: 494499.

Vitousek, P.M.; H.A. Mooney; J. Lubchenco \& J.M. Melillo. 2008. Human Domination of Earth's Ecosystems, p. 3-14. In: J.M. Marzluff; E. Shulenberger; W. Endlicher; M. Alberti; G. Bradley; C. Ryan; U. Simon \& C. Zumbrunnen (Eds). Urban Ecology: An International 50 Perspectives on the Interaction Between Humans and Nature. New York, Springer.

Walsh, C.J.; A.H. Roy; J.W. Feminella; P.D. Cottingham; P.M. GrofFMAN \& R.P. MoRgan II. 2005. The urban stream syndrome: current knowledge and the search for a cure. Journal North American Benthological Society 24: 706-723.

Winemiller, K.O.; A.A. Agostinho \& P.E. Caramaschi. 2008. Fish Ecology in Tropical Streams, p. 336-346. In: Dudgeon, D. (Ed.). Tropical Stream Ecology. California, Academic Press, 370p. Zeug, S.C. \& K.O. Winemiller. 2008. Evidence Supporting the Importance of Terrestrial Carbon in a Large-River Food Web. Ecology 89 (6): 1733-1743.

Submitted: 21.VII.2011; Accepted: 30.XI.2011.

Editorial responsibility: Vinicius Abilhoa 